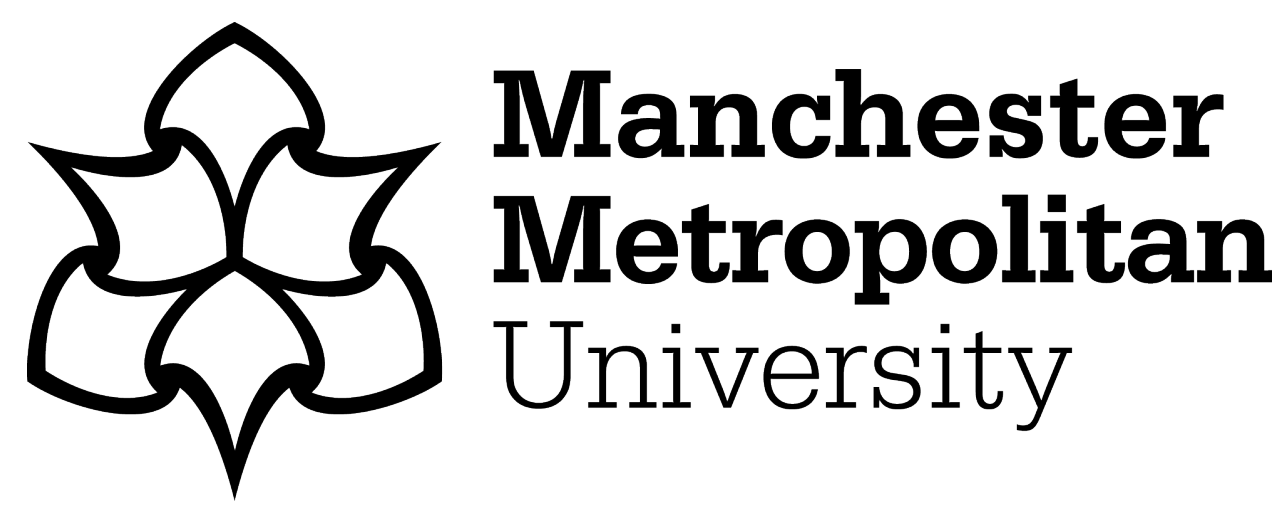

Raj, Senthorun ORCID logoORCID: https://orcid.org/0000-0001-6972-9252 (2021) Teaching feeling: bringing emotion into the law school. The Law Teacher, 55 (2). pp. 128-142. ISSN 0306-9400

Downloaded from: https://e-space.mmu.ac.uk/628633/

Version: Accepted Version

Publisher: Taylor \& Francis

DOI: https://doi.org/10.1080/03069400.2020.1781456

Please cite the published version 


\title{
Teaching feeling: bringing emotion into the law school
}

\author{
Senthorun Raj \\ School of Law, Keele University, Newcastle-under-Lyme, UK
}

\begin{abstract}
This paper explores the dynamics of emotion in law and legal classrooms by showing: (1) why foregrounding how law is shaped by emotion better equips students to learn about how law advances and/or inhibits various pursuits of social justice and (2) how emotion functions as a useful pedagogical strategy in the classroom to make students receptive enough to empathetically and critically engage with pressing legal questions about social justice. This paper fleshes o ut the i mportance of foregrounding emotions in legal classrooms through an autoethnographic account of designing and teaching an undergraduate elective law module called Law and Emotion. By synthesising critical legal studies, law and emotion scholarship, and social theories of teaching/learning with observ ations from module design, deliv ery, assessment, and ev aluation, this paper illuminates the pedagogical importance of making law, law teachers, and law students engage critically with their feelings.
\end{abstract}

ARTICLE HISTORY Received 22 April 2020; Accepted 9 June 2020

KEYWORDS Emotion; law; justice

\section{Introduction}

Recent newspaper editorials have criticised the increasing "snowflake sensitivities" of university students and classroom dynamics. Universities generally and humanitiesbased disciplines specifically have come under incredible political scrutiny for being "ideological", " "politically correct", 2 and "censorious" ${ }^{3}$ for presuming or pandering to student vulnerabilities. Academics have responded to these critiques by highlighting how shifting disciplinary expectations, pedagogical styles, and curriculum content reflect the changing nature of universities and students. ${ }^{4}$

\footnotetext{
CONTACT Senthorun Raj s.raj@keele.ac.uk E School of Law, Keele University, Newcastle-under-Lyme, UK 'David Matthews, "Gender Studies under Attack from the New Right" The Times Higher Education (London, 10 May 2017) <www.timeshighereducation.com/news/gender-studies-under-attack-from-new-right> accessed 1 June 2020.

2Damon Linker, "How Conservatives Out-Intellectualized Progressives" (The Week, 6 December 2016) <https:// theweek.com/articles/665446/how-conservatives-outintellectualized-progressives> accessed 1 June 2020.

${ }^{3}$ Katharine Gelber, "There's No Need for the 'Chicago Principles' in Australian Universities to Protect Freedom of Speech" (The Conversation, 15 November 2018) <https://theconversation.com/theres-no-need-for-the-chicago -principles-in-australian-universities-to-protect-freedom-of-speech-107001> accessed 1 June 2020.

${ }^{4}$ Fabian Cannizzo, "The Love of Labour in Academia" (The Sociological Review Blog, 11 August 2017) <www. thesociologicalreview.com/the-love-of-labour-in-academia/> and Sabelo Ndlovu-Gatsheni, "Decolonising Research Methodology Must Include Undoing Its Dirty History" (The Conversation, 26 September 2017) $<$ https://theconversation.com/decolonising-research-methodology-must-include-undoing-its-dirty-history -83912> accessed 1 June 2020.
} 
These broader public debates speak to a range of pressing concerns about the susceptibility of higher education to emotional compromise. One particular concern that emerges from these debates is how the accommodation of emotions (of students in particular) in university classrooms inhibits the intellectual development of students by allowing feelings to replace reason or debate. Higher education is compromised when student feelings are taken seriously in the curriculum. Nowhere is this concern more apparent than in a legal classroom, which most imagine as a pedagogical space where legal academics train future lawyers to leave their feelings behind. We teach them law as a dispassionate system of rules that can be studied systematically and then used to rationally resolve disputes. ${ }^{5}$

Contrary to this popular view, however, emotion is not "queer" to law - it is imbricated in both law (as a discrete subject/object to study) and legal study (as a strategy of learning). This paper explores this imbrication by showing: (1) why foregrounding how law is susceptible to emotion allows students to learn about how law advances and/or inhibits various pursuits of law reform and (2) how emotion functions as a pedagogical strategy in the classroom to make students receptive enough to empathetically and critically engage with questions of law and justice. This paper fleshes out the importance of bringing emotion into legal classrooms through an autoethnographic account of designing and teaching a module called "Law and Emotion" at Keele University. By synthesising critical legal studies, law and emotion scholarship, and social theories of teaching/learning with personal observations from module design, delivery, assessment, and evaluation, this paper illuminates why and how we as law teachers should foreground emotion in the classroom.

\section{Emotion and legal education}

It is necessary to start with an outline of how emotion has gained academic traction in law and legal education. This theoretical grounding provides an important starting point for academic lawyers who are thinking about embarking upon the analysis and/or teaching of emotion in law.

Affect, emotion, and feeling have different dimensions. Affect is an ethology: moments of action, non-conscious experience or unstructured potentials. ${ }^{6}$ In contradistinction, emotion can be framed as a distinctive political and social marker that "sticks" to a body or community, often produced through subject-object relations. ${ }^{7}$ Emotions are the narrative subtraction from affect. ${ }^{8}$ Feeling, alternatively, is the personalised recognition of our affective and emotional histories. ${ }^{9}$ Feeling is a means by which we recognise or understand experience and communicate politics. ${ }^{10}$ Emotion

\footnotetext{
${ }^{5}$ Rosalind Dixon, "Studying Law Is About Much More than Becoming a Lawyer, Malcolm Turnbull" (ABC News, 2 February 2018) <www.abc.net.au/news/2018-02-02/prime-minister-malcolm-turnbull-unsw-study-law-hassatar/9390698?pfmredir=sm > accessed 1 June 2020.

${ }^{6}$ Gilles Deleuze, "Ethology: Spinoza and Us" in Jonathan Crary and Sanford Kwinter (eds), Incorporations (Zone Books 1992) 626.

${ }^{7}$ Eric Shouse, "Feeling, Emotion, Affect" (2005) 8(6) M/C Journal 1, 1-2.

${ }^{8}$ Patricia Ticineto Clough, "Introduction" in Patricia Ticineto Clough (ed), The Affective Turn: Theorizing the Social (Duke University Press 2007) 2.

${ }^{9}$ Shouse (n 7) 1.

${ }^{10}$ Lauren Berlant, The Queen of America Goes to Washington City: Essays on Sex and Citizenship (Duke University Press 1997) 5-6; Audre Lorde, Sister Outsider (Crossing Press 1984) 59; Joan Scott, "The Evidence of Experience" (1991) 17 Critical Inquiry 773, 773.
} 
and feeling, then, can be understood as relational and cognitive expressions. Sara Ahmed examines how these social forms of emotion take shape by focusing on "impressions". Emotions manifest themselves through our shared vulnerabilities: others (im)press upon us (creating feelings), we form impressions (creating thoughts), and impressions mark surfaces and spaces (creating objects). ${ }^{11}$

Confronting emotions - as forms of social impressions and relationalities - poses serious challenges in law. Positivist accounts of law, inspired by the pioneering work of jurist HLA Hart, purport to define "the law" as a unique system of norms, rationalities, rules, commands, and obligations. ${ }^{12}$ What this articulation of law obscures, however, is how emotions crystallise in jurisprudence, legislation, and litigation. Scholars working in the intersection of law and emotion establish that legal institutions, including law schools, continue to insist upon a script of "judicial dispassion" or "rationality" of the legal subject as a cornerstone principle of law. ${ }^{13}$ Emotion is construed as antithetical to (learning about) law. ${ }^{14}$ These attempts to exile emotion from the (study of) law can be dangerous, as this risks trivialising complex disputes and cementing caricatured ideas of "rational decisions". ${ }^{15}$ It also risks obscuring how expectations about rationality sustain forms of power and modes of marginalisation. ${ }^{16}$ Addressing this is not simply a matter of recognising power but requires us to make space for what Jill Stauffer describes as "ethical loneliness". Ethical loneliness describes the state of isolation caused by human and institutional abandonment (inequality, dehumanisation, oppression, injustice, etc.) coupled with a person's inability to have their voice or testimony "heard" by the world around them. ${ }^{17}$

If law seeks to engage with human experiences of inequality and abandonment, then law students need to be able to "hear" stories in a way that does not presume that the ideal (legal) listener to such stories is emotionally indifferent nor does it presume law is a rational frame in which these stories can be told. ${ }^{18}$ Emotion, then, is not a state that necessarily needs to be "overcome" in law or legal study. Rather, it is a relational space where law students can intimately connect to matters of injustice and affectively reflect on the scope of law to repair them. This requires law teachers to challenge the idealised "emotional distance" that structures teacher-student, teacher-subject, and student-subject relationships. ${ }^{19}$

Challenging emotional distance is a departure point for law teachers to craft a critical pedagogical framework that makes space for learning about, and learning with, emotions when addressing legal topics concerned with (in)equality and (in)justice. ${ }^{20}$ This

\footnotetext{
${ }^{11}$ Sara Ahmed, The Cultural Politics of Emotion (Edinburgh University Press 2004) 6.

${ }^{12}$ HLA Hart, The Concept of Law (Oxford University Press 1994) 88-90.

${ }^{13}$ Kathryn Abrams and Hila Keren, "Who's Afraid of Law and the Emotions?" (2010) 94 Minnesota Law Review 1997, 1999; Terry A Maroney, "The Persistent Cultural Script of Judicial Dispassion" (2011) 99 California Law Review 629, 633-40.

${ }^{14}$ Bettina Lange, "The Emotional Dimension in Legal Regulation" (2002) 29 Journal of Law and Society 197, 199.

${ }^{15}$ Abrams and Keren (n 13) 1999.

${ }^{16}$ Martha Fineman, "Vulnerability and Inevitable Inequality" (2017) 4 Oslo Law Review 133, 142.

${ }^{17}$ Jill Stauffer, Ethical Loneliness: The Injustice of Not Being Heard (Columbia University Press 2015) 1.

18 ibid 77.

${ }^{19}$ Garrett W Nichols, "Queer Settlers in a One-Room Schoolhouse: A Decolonial Queerspace Pedagogy" in Elizabeth McNeil, James E Wermers and Joshua O Lunn (eds), Mapping Queer Space(s) of Praxis and Pedagogy (Palgrave 2018) 51.

${ }^{20}$ This is not to imply that emotions are universally experienced or useful in all contexts, especially when accounting for the diverse ways people learn and (do not) feel about a set topic. See Julian Webb, "The Body in (E)Motion: Thinking Through Embodiment and Legal Education" in Paul Maharg and Caroline Maughan (eds), Affect and Legal Education: Emotion in Learning and Teaching the Law (Routledge 2016).
} 
challenge prompts a range of pedagogical questions. What does it mean to learn about how law recognises and manages emotions and positionalities? Why should law schools make space for emotions when reading cases or using statutes to understand "the law" and its relationship to "justice"? How might legal education that centres emotion allow students to critically engage with issues of social justice?

To answer these questions, we have to be clear about the varied purposes of "legal education". Legal education varies in terms of jurisdiction, institution, and curriculum. In common law countries, these variations are contingent on whether programmes aim to be academic (to engage in a critical study of law), clinical (to learn law and apply law in practical contexts), or vocational (to develop the professional skills necessary for legal practice) in orientation. ${ }^{21}$ These programmatic orientations, however, make little room for emotion. Whether it requires memorising civil procedure rules for litigation or theorising about case law, legal teaching primarily relies on engaging with students' (rational) cognitive capacities to develop their legal knowledge and skills. ${ }^{22}$ As Duncan Kennedy notes, such forms of legal education are impeded by the fiction, the ideology, that students should develop "autonomous legal reasoning" by distinguishing between law (as a field of demarcated doctrines) and policy (as a field that invites uncertainty and debate). He notes:

Law schools teach these rather rudimentary, essentially instrumental skills in a way that almost completely mystifies them for most law students ... the schools teach skills through class discussions of cases in which it is asserted that law emerges from a rigorous analytical procedure called legal reasoning, which is unintelligible to the layperson but somehow both explains and validates the great majority of the rules in force in our system. ${ }^{23}$

With this in mind, it is unsurprising that affect and emotion, unlike cognition and reason, are not valued as parts of a formalised system of analytic legal study. Rather, many law teachers present emotion as the antithesis of legal reasoning. Feelings, unlike law, are disordered and unpredictable. ${ }^{24}$ Such framings of law also render emotion as a pedagogical threat to effective legal learning: emotions disrupt and distract from the development of propositional knowledge and reasoning. Caroline Maughan, with a greater focus on emotion than Kennedy, contests these framings and argues that "deep learning" in law school requires an engagement with emotion. She suggests law teachers must engage with the motivations and emotional experiences of students, as emotion underscores the pleasure of learning and curiosity that stem from deep learning approaches. ${ }^{25}$

\section{Designing law and emotion}

I use autoethnography to foreground my practice in teaching Law and Emotion. This method situates the scholar within their field of study (legal pedagogy) and combines personal observations or reflections (pedagogical practice) with literature that frames

\footnotetext{
${ }^{21}$ Duncan Kennedy, "Legal Education as Training for Hierarchy" in David Kairys (ed), The Politics of Law (Basic Books 1998); Caroline Maughan, "Why Study Emotion?" in Paul Maharg and Caroline Maughan (eds), Affect and Legal Education: Emotion in Learning and Teaching the Law (Routledge 2016) 20-24.

${ }^{22}$ Fiona Cownie, Anthony Bradney and Mandy Burton, English Legal System in Context (6th edn, Oxford University Press 2013) 125-26.

${ }^{23}$ Kennedy (n 21) 59 .

${ }^{24}$ Maughan (n 21) 19.

${ }^{25}$ ibid 27.
} 
those observations (pedagogical scholarship). ${ }^{26}$ As Stephen Brookfield notes, this approach is commended for academics who wish to "become critically reflective teachers" because it enables us to consider whether our emotional impulses or responses to conversations or activities align with the students we teach and enables us to perceive the ways performance, classroom arrangements, and evaluative options structure learning environments. ${ }^{27}$ An autoethnographic approach is useful to analyse Law and Emotion because it allows me to situate my emotional experiences of teaching alongside the disciplinary expectations, institutional constraints, and classroom dynamics that come with teaching about emotion in law.

The first point to note is that Law and Emotion was not a core module required for the LLB. Designing an elective law module - unlike compulsory ones - freed me from the disciplinary constraints prescribed by the Solicitors Regulation Authority and Bar Standards Board. In terms of content, I had the space to design a module according to my research expertise, which spanned law and cultural studies. This shifted my focus away from thinking about what I was required to teach and how to do it to thinking about what I desired to teach and why. What did I value about law? What did I want my students to value about it? My initial responses to these questions took me back to the passions I had when I started law school as a precocious student: I wished to become a lawyer to instrumentalise law as a means of securing justice for marginalised groups of people. As an undergraduate, I found the study of law represented a means for me to achieve an end of social and political justice. This reflection prompted me to think about whether the students I taught in first year felt the same (some had already disclosed this to me in our first year classes) and, for those who did not share such concerns, I also wondered how I might be able to get them to think critically about law within its social and political context.

Module design, however, does not emerge simply from the passions of its designer. It is inevitably indexed against the changing institutional demands of higher education and internal policies on curriculum design. ${ }^{28}$ Stefan Collini identifies this as a challenge for academics that routinely find themselves in defensive positions, having to articulate what makes their research and teaching distinctive or valuable. ${ }^{29}$ He suggests academics need to focus more on the values of a particular discipline, rather than seeking to reduce it to a single "point" about impact. ${ }^{30}$ Keele University's Teaching and Learning Strategy 2020, for example, sits within this context and some parts of it resonate with Collini's proposition: it identifies the importance of interdisciplinary and inclusive education that fosters intellectual discussion (Strategic Aim 3) while providing opportunities for students to be more socially engaged beyond the curriculum (Strategic Aim 5). ${ }^{31}$ In the School of Law, the programme specification makes clear that what makes the School's curriculum "distinctive" is that students are introduced to law in its social, political, economic, and historical context in an interdisciplinary and research-led classroom. ${ }^{32}$ Such strategies and

\footnotetext{
${ }^{26}$ Patricia Williams is a critical legal scholar who has written extensively on the value of situating oneself in relation to one's object of study, as a way to explore the "embodied" or "personal" dimensions of legal pedagogy and scholarship. See Patricia Williams, The Alchemy of Race and Rights: The Diary of a Law Professor (Harvard University Press 1992).

${ }^{27}$ Stephen Brookfield, Becoming a Critically Reflective Teacher (Jossey-Bass 1995) 13, 51.

${ }^{28}$ Keith Trigwell, "Judging University Teaching" (2001) 6 International Journal for Academic Development 65, 69.

${ }^{29}$ Stefan Collini, What Are Universities For? (Penguin Books 2012) 89.

${ }^{30}$ ibid 101.

${ }^{31}$ Keele University, "Teaching and Learning Strategy to 2020" (2015) <www.keele.ac.uk/media/keeleuniversity/ policyzone20/studentandacademicservices/L\&T\%20Strategy\%20FinalWEB.pdf> accessed 1 June 2020.

${ }^{32}$ Keele University School of Law <www.keele.ac.uk/law/> accessed 1 June 2020.
} 
policies echo the "liberalisation" of law schools to embrace critical perspectives and social justice agendas. ${ }^{33}$ Higher education aspirations for student social or civic engagement coupled with law programme expectations for interdisciplinary learning were strategically important to anchor the development of a module that introduced students to the study of law and emotion.

Law and Emotion took shape in response to my emotional questions about how to confront matters of justice and politics in/through law, and as such, derived its conceptual foundations from existing work in critical legal studies that has grappled with such questions. ${ }^{34}$ In writing about US law schools, Kennedy argues that doctrinal legal education recuperates ideological privileges and social hierarchies. ${ }^{35}$ Legal education normalises the status quo through assessment practices, valorisation of certain forms of legal practice, teaching of doctrine rather than practice, relationship models offered by teachers, race, class and gender norms, and ritualistic behaviours that rely on "masking" social hierarchies. ${ }^{36}$ For Kennedy, legal classrooms must endeavour to address questions of justice by engaging with, and critiquing, law as it operates on an existing social terrain - rather than as an abstract set of rules or norms that are applied to hypothetical problems. As Patricia Williams writes, addressing inequalities or injustices requires us to think about that which is "underseen" in law and legal classrooms, which typically relates to the emotions and identities of those who are socially marginalised. ${ }^{37}$

Critical legal studies make apparent the pedagogical value of teaching law in a social context. And, while not always explicitly foregrounding emotion in their work, critical legal studies highlight how emotion can be used as both a pedagogical strategy to think about (in)justice and an analytic framework to understand how particular justice claims are pursued and crystallised in law. ${ }^{38}$ In other words, pursuing social justice through legal education requires a focus on giving students experiential learning by taking responsibility for learning and applying theory to practice, developing an affective social-legal consciousness that enables students to see the impact of law on society, and addressing community needs through the development of technically proficient lawyers with ethical sensibilities. ${ }^{39}$ As Alan Lerner argues:

If we want our law students to make the most of their cognitive powers, we need to help them understand the power of their emotional minds. We need to re-examine what it means to teach them to "think like [the] lawyers [we would like them to become]" and integrate awareness of the role of their, and everyone else's, emotions in making the right decisions. ${ }^{40}$

${ }^{33}$ Jessica Guth, "Social Justice: Education for Sustainable Development in Law Schools" in Chris Ashford and Paul McKeown (eds), Social Justice and Legal Education (Cambridge Scholars Publishing 2018) 307.

${ }^{34}$ See Ronald Dworkin, Law's Empire (Harvard University Press 1987); Ruthann Robson, Sappho Goes to Law School: Fragments in Lesbian Legal Theory (Columbia University Press 1998), Robin West, "Communities, Texts and Law: Reflections on the Law and Literature Movement" (1988) 1 Yale Journal of Law \& Humanities 129; James Boyd White, "Law as Language: Reading Law and Reading Literature" (1981) 60 Texas Law Review 415; Patricia Williams, "On Being the Object of Property" (1988) 14 Signs: Journal of Women in Culture and Society 5.

${ }^{35}$ Kennedy (n 21) 58-60.

${ }^{36}$ ibid 60-62.

${ }^{37}$ Williams (n 34) 5.

${ }^{38}$ I have written in much more detail about the latter point when it comes to how "reading emotion" is useful for legal scholars, activists, lawyers, and judges interested in unpacking the limits and possibilities of pro-LGBT rights jurisprudence. See Senthorun Sunil Raj, Feeling Queer Jurisprudence: Injury, Intimacy, Identity (Routledge 2020).

${ }^{39}$ Richard Grimes, "Experimental Learning, Legal Schools and a Social Mission: Whose Justice, What Justice?" in Chris Ashford and Paul McKeown (eds), Social Justice and Legal Education (Cambridge Scholars Publishing 2018) 257. 
Cognitive dimensions of individual student learning focus on how individuals process and deal with new information. Barbel Inhelder and Jean Piaget explored the socialised context of how we process new information and developed two key concepts to understand childhood learning: (1) stages of cognitive development impact on how we learn (such as different forms of learning at different times in life) and (2) assimilation (such as familiar experiences are incorporated easily into an existing cognitive structure) and accommodation are key to processing of information (such as the way individuals adapt to new knowledge that challenge their pre-existing cognitive structure). ${ }^{41}$ Neuroscience provides an important explanatory framework for understanding this socialised processing and retention of information. Richard Roche notes that rich and evocative examples, for instance, promote improved retention of facts by locating the meaning of material in personal and social contexts. ${ }^{42}$

By bringing together Inhelder, Piaget, and Roche's ideas of social learning with Kennedy and Williams' insistence on social justice-informed legal study, I designed Law and Emotion to scaffold students' own (emotional) experiences in relation to a range of current (emotional) legal case examples or debates about social justice. To that end, Law and Emotion had four key learning outcomes. I wanted students to:

(1) Articulate current debates in the field of Law and Emotion.

(2) Differentiate between conceptual approaches when analysing the relationship between law and emotion.

(3) Critically reflect on the role of emotion in various legal issues/problems (including by reflecting on core modules previously studied) and how to contextualise legal issues/problems by using emotion.

(4) Evaluate the function and effect of emotions in addressing legal issues/ problems.

To situate debates in Law and Emotion, I crafted the theoretical foundations of the module by drawing on scholarship from neuroscience, psychology, behavioural economics, sociology, and cultural studies to show how emotions come to matter in the law as sites of evaluation, thought, pedagogy, imagination, preference, and normativity. ${ }^{43}$ In sketching a taxonomy of emotion scholarship in law, Terry Maroney identifies what she sees as the six key approaches to study: (1) focus on how an emotion can or should be reflected in law; (2) identify the legal mechanisms that express emotion; (3) elaborate particular theories of emotion; (4) examine how legal doctrine sediments emotion; (5) analyse the relationship between theories of emotion and law; and (6) explore how legal actors are or should be influenced by emotion. ${ }^{44}$ Designing

\footnotetext{
${ }^{40}$ Alan M Lerner, "From Socrates to Damasio, from Langdell to Kandel" in Paul Maharg and Caroline Maughan (eds), Affect and Legal Education: Emotion in Learning and Teaching the Law (Routledge 2016) 172.

${ }^{41}$ See Barbel Inhelder and Jean Piaget, The Growth of Logical Thinking from Childhood to Adolescence: An Essay on the Construction of Formal Operational Structures (Routledge and Kegan Paul 1958).

${ }^{42}$ Richard Roche, "Learning and the Brain - An Overview" in Paul Maharg and Caroline Maughan (eds), Affect and Legal Education: Emotion in Learning and Teaching the Law (Routledge 2016) 63.

${ }^{43}$ David J Arkush, "Situating Emotion: A Critical Realist View of Emotion and Nonconscious Cognitive Processes for Law and Legal Theory" (2008) 5 Brigham Young University Law Review 1275; Terry A Maroney, "Law and Emotion: A Proposed Taxonomy of an Emerging Field" (2006) 30 Law and Human Behavior 119; Terry A Maroney, "The Persistent Cultural Script of Judicial Dispassion" (2011) 99 California Law Review 629; Eric A Posner, "Law and the Emotions" (2001) 89 Georgetown Law Journal 1977.

${ }^{44}$ Maroney, "Law and Emotion" (n 43) 119.
} 
a module within this interdisciplinary context was key to enable students to differentiate between theoretical approaches to understand emotion and law, and their relationship to each other. This pedagogical approach also relates to the social and political context of teaching law: the module would provide students with theoretical tools to explore the (elusive) nature of social justice, both what it means and how it is operationalised or subverted through law and legal processes. ${ }^{45}$ The module connected students' existing legal knowledge and understanding of legal issues (based on core modules like Torts and Public Law they previously studied) with new theoretical ideas. This connective approach gives students a familiar base or anchor of knowledge to begin to navigate the role and nature of emotion in law. ${ }^{46}$

Unlike core law modules that require students to learn "the law" to apply to specific factual scenarios, Law and Emotion sought to engage students in comprehension, analysis, synthesis, and evaluation of the function and effect of emotion in law rather than memorisation or recall of legal rules. ${ }^{47}$ Taking account of the "emotional fabric" of law also is not simply an academic exercise - it has vocational importance: it enables lawyers to better understand the needs and desires of those they represent or interact with in the profession. ${ }^{48}$

Scaffolding a teaching structure to assist students in achieving the learning outcomes necessitated thinking about how best to cultivate student curiosity, motivation, and capacities for critical reflection. ${ }^{49}$ Facilitating autonomous learning requires teachers to take seriously the personhoods of those they teach and what they care about, which may differ from those of teachers..$^{50}$ In terms of module content, I selected a range of emotions and legal issues or case studies to appeal to diverse interests. Rather than organise the module within a specific jurisdiction or area of law (which is typical of core law modules), this module would invite students to think about emotions - both "good" and "bad" ones - as a way to navigate legal debates across disciplines and jurisdictions. The first couple of seminars would contextualise debates in Law and Emotion. Each subsequent seminar would then focus on a specific emotion and explore how such emotion animates or addresses a contemporary legal issue or problem. I paired disgust with sexual offences, hate with hate crime, shame with punishment, pain with transitional justice, fear with asylum, suspicion with psychiatric injury, love with kinship, and hope with human rights. In order to maintain student interest and engage with the social justice desires animating the module, the module aimed to cover a range of emotions alongside a range of current law reform debates. The module also covered a range of legal subdisciplines (criminal law, tort law, international law, family law, refugee law, and family law, etc.) and legal texts (statutes, policies, case law, law reform reports, etc.).

${ }^{45}$ Lucy Yeatman, "Law in the Community and Access to Justice: Linking Theory and Practice" in Chris Ashford and Paul McKeown (eds), Social Justice and Legal Education (Cambridge Scholars Publishing 2018) 132.

${ }^{46}$ See Jerome Bruner, The Process of Education (Harvard University Press 1960).

${ }^{47}$ See Benjamin S Bloom, Taxonomy of Educational Objectives (Allyn and Bacon Press 1956).

${ }^{48}$ Maksymilian Del Mar, "Legal Understanding and the Affective Imagination" in Paul Maharg and Caroline Maughan (eds), Affect and Legal Education: Emotion in Learning and Teaching the Law (Routledge 2016) 187; Marcia Devlin and Gayani Samarawickrema, "The Criteria of Effective Teaching in a Changing Higher Education Context" (2010) 29 Higher Education Research \& Development 111, 121.

${ }^{49}$ George Hess, "The Teaching and Learning Environment in Law School" (2002) 52 Journal of Legal Education 75, 83; Devlin and Samarawickrema (n 48) 112.

${ }^{50}$ Graham Ferris and Rebecca Huxley-Binns, "What Students Care About and Why We Should Care" in Paul Maharg and Caroline Maughan (eds), Affect and Legal Education: Emotion in Learning and Teaching the Law (Routledge 2016) 198. 
This paired approach made it possible to anchor the wide-ranging scope of specific law reforms to a particular emotion. Drawing on Ahmed, emotion (such as fear) would be a social lens to explore the limits and possibilities of law reform aimed at addressing contemporary problems (such as refugee status determination). ${ }^{51}$ The reading list for each week included an academic article about the topic and a current article from the news related to it. The purpose of limiting the amount of required reading and including a topical news issue was to allow students time to reflect on what they had read and think about the connections between theorisations of emotion and expressions of emotion in legal spheres. The module also had a soundtrack. The purpose of the soundtrack was to use music - drawn from a range of cultures and genres - to allow students to hear and feel emotions as a way of making sense of the topic to be discussed each week. Law and Emotion embraced a "queer legal pedagogy" by troubling normative views of law and questioning expectations of justice while also complicating how we define or understand appropriate legal study or scholarship. ${ }^{52}$ This rationale was clear in the module outline (accessible online before the first class).

\section{Teaching with feeling}

Law and Emotion aimed to create spaces for critical discussion and reflection on law. This required me to confront the fact that students orient themselves to learning law in different ways. Some students focus exclusively on legal materials (such as cases, statutes, treaties) in order to think of the law as a discrete object to be studied. Others take a more interdisciplinary approach and consider the way law operates in a broader social context (not just statutes and case law). Facilitating a dialogue between these different orientations to the study of law is challenging. Students may be more capable of critical discussion when they are able to position how they personally think about the subject material. ${ }^{53}$ To that end, the module was structured as a small group seminar (there were 10 students in the class) delivered over $10 \times 2$ hour sessions over the semester. I relied on a range of learning activities to encourage wide-ranging student participation. In each seminar, we discussed a specific emotion and paired it with a current legal debate. While the legal topics canvassed in the module (sexual offences, hate crimes, refugee decision-making, trans legal recognition, marriage equality, etc.) invite consideration of a range of different emotional responses (from litigants, lawyers, judges, etc.), choosing a single emotion as a lens for each week provided a useful anchor to analyse the legal issue/problem set for the week's class. In each seminar, I attempted to open up space for discussion by using a prompt (such as a Disney character from the movie Inside Out). In a class on disgust, for example, I asked students to brainstorm how they felt or images that came to mind when I said the word "disgust". This initial prompt generated some general responses about "ickyness" or "grossness". I then asked students to connect these single word responses to personal experiences they had. I asked them to reimagine that experience and narrate what was involved (physical reactions, social responses, personal consequences, etc.). The affective dimension of imagination structures how we grasp specific

\footnotetext{
${ }^{51}$ Ahmed (n 11) 1-19.

${ }^{52}$ Ruthann Robson, "Educating the Next Generation of LGBTQ Social Justice Attorneys" in Chris Ashford and Paul McKeown (eds), Social Justice and Legal Education (Cambridge Scholars Publishing 2018).

${ }^{53}$ Emily M Gray and Lucy Nicholas, "'You're Actually the Problem': Manifestations of Populist Masculinist Anxieties in Australian Higher Education" (2019) 40 British Journal of Sociology of Education 269, 274.
} 
possibilities associated with certain terms, phrases, or experiences. ${ }^{54}$ Asking students to reflect on emotional moments effectively demonstrated how they used their personal experiences to generate broader dialogue aimed at theorising emotion. I could then follow up these points with further questions and comments in order to get students to then focus on the legal subject material.

In the classroom, students' capacities to reflect on personal positioning (to talk about their feelings) were key to our dialogues and promoting greater student participation. Students who were able to recognise their "starting points" (such as their assumption about whether disgust was a negative emotion or whether certain kinds of sex were disgusting) were better able to discuss issues in a respectful and rigorous way. Reflective practice involves thinking about what we do and how we learn through different lenses. Brookfield writes that reflective practice is critical for teachers to scrutinise assumptions and recognise how pedagogical practices can mask particular power relationships or dynamics and hegemonic beliefs about what constitutes good practice. ${ }^{55}$ I would extend Brookfield further and suggest this is a practice to cultivate among students: scrutinising emotions allows them to understand how law can mask power dynamics and understand how emotions create hegemonic beliefs about law and the value of law reform. Disgust, for example, is routinely embraced in criminalising conduct (such as public nudity) that offends public sensibilities. ${ }^{56}$ By "thinking somatically" we can see how learning is embodied through the content of what we teach (i.e. disgust in criminal law) and the methods we use to teach it (i.e. reflecting on the disgust we feel towards the law or the conduct it addresses). Foregrounding this relationship allows us as law teachers to construct an "affective interface between curriculum and pedagogy". ${ }^{57}$ Therefore, I encouraged students to explain their emotional positioning through references to the module readings to ensure that discussion remained focused and relevant (this also helped students who were less comfortable drawing on their experiences or anecdotes). In doing so, I came to appreciate how teachers could play an important role in facilitating reflective discussion by initially asking broad questions that invite disparate responses and then anchoring (some of) those responses more specifically to the subject matter of the module. In each seminar, this included: asking students to define the specific terms they used, clarifying the context of their statements, identifying or asking for connections to the reading materials, and acting as a "devil's advocate" and urging students to consider counterpoints or counterfactual scenarios to points they raised. This pedagogical use of emotion helps students break apart particular forms of knowledge and provides tools for them to rebuild new schemas of knowledge.

Foregrounding emotion in the legal classroom generates vulnerability and this carries certain opportunities and risks. The classroom is ill equipped to be a therapeutic space and we should be acutely aware that law classrooms and curriculums (especially when taught in an adversarial and competitive context) have adverse impacts on the mental health of students. ${ }^{58}$ I aimed to address this challenge by making emotional literacy and personal wellbeing part of the module. The module outline

\footnotetext{
${ }^{54}$ Del Mar (n 48) 182.

${ }^{55}$ Brookfield (n 27) xiii.

${ }^{56}$ Martha C Nussbaum, Hiding from Humanity: Disgust, Shame, and the Law (Princeton University Press 2004).

${ }^{57}$ Webb (n 20) 212.

${ }^{58}$ See Jerome Doraisamy, The Wellness Doctrines: For Law Students and Young Lawyers (SelfPublished 2015); Hess (n 49) 77.
} 
identified the topics under discussion each week and students were advised they could leave if they found the content "triggering". However, I also wanted the classroom to challenge student views and become a space for generating pedagogical discomfort. This tension could be partially addressed by foregrounding emotion and embodiment in the legal classroom to enable students to navigate their personal emotions alongside challenging legal topics. ${ }^{59}$ The seminars utilised a range of teaching activities: visual material (graphics or memes), personal anecdotes (student experiences), guided discussions (paired or group work to discuss a legal problem), and reflections on the readings or song choice (sharing key points, praise, and critiques) to create a space where students could: examine emotions; understand the role of emotions in conflicts and dispute resolution; reflect on their emotions; and engage in "self-work" to recognise and manage their emotional responses in relation to what they were discussing in class. $^{60}$

\section{Grounding assessments}

Teaching emotion also had an impact on assessment decisions. In crafting an assessment regime, I was guided by my university's policy on "assessment literacy" which involves ensuring students understand the reasons behind, and nature of, assessment. ${ }^{61}$ The principles, which echo approaches taken by universities more broadly, prescribe that assessments should be designed at programme level, integral to curriculum, integral to students' approach to learning, purpose clearly communicated, linked to learning outcomes, reliable, robust, and fair, students receive meaningful and timely feedback, transparent criteria, redeemable, inclusive, manageable, and efficient. In law schools, undergraduate assessments primarily involve exams (a combination of hypothetical problems and essays) or assignments (a research essay or presentation). I opted for a research essay. The assessment was explicitly not about decontextualising knowledge to seek an "objective" understanding of specific legal rules or procedures. ${ }^{62}$ As the module was designed to cultivate autonomous learning and reflection, I wanted students to write about what interested them. This self-directed approach to assessment would "constructively align" students' interests in relation to a legal topic and provide an opportunity for them to follow their feelings to critically reflect on how emotion shapes a particular legal issue. ${ }^{63}$ This models what Bradford Imrie describes as "assessment for learning" where teachers provide guidance for students to develop their knowledge through the assessment process. ${ }^{64}$

In Law and Emotion, students could adopt the seminar design as a structure for their essays (select an emotion and pair it with a legal topic or debate). Students were encouraged to use stimuli from their own life (books, films, tweets, encounters, etc.) to begin their essays. I urged students at the beginning of the module to use the social

\footnotetext{
${ }^{59}$ See Sarah Schulman, Conflict Is Not Abuse: Overstating Harm, Community Responsibility, and the Duty of Repair (Arsenal Pulp Press 2016).

${ }^{60}$ Hess (n 49) 105; Webb (n 20) 214.

${ }^{61}$ Keele University, "Assessment Principles" (2018) <www.keele.ac.uk/policyzone/data/assessmentprinciples/> accessed 1 June 2020.

${ }^{62}$ Bradford W Imrie, "Assessment for Learning: Quality and Taxonomies" (1995) 20 Assessment \& Evaluation in Higher Education 175, 180; Webb (n 20) 219.

${ }^{63}$ John Biggs, "Enhancing Teaching through Constructive Alignment" (1996) 32 Higher Education 347, 348; Hess (n 49) 97.

${ }^{64}$ Imrie (n 62) 188.
} 
media platform Pinterest to "pin" articles of interest that related (even tangentially) to current legal issues. I advised that they should consult their Pinterest "board" for ideas when beginning to craft an essay question, as there may be shared themes and/or feelings in relation to the content they had "pinned". Students pursued essay questions on resentment in the criminal justice system with reference to recent Twitter movements for \#BlackLivesMatter and anger in the context of \#MeToo and sexual harassment law citing contemporary media discourses. This assessment method would also prepare students for final year law modules, especially for students who wished to pursue a dissertation in their final year or undertake community or clinical placements (where they would be required to write a reflective essay about their work with clients).

The assessment approach required clear expectations and guidance in relation to the learning outcomes mentioned earlier. This was the first time students were undertaking an independent research project in their law studies. Students in the module were first required to write a research proposal (1000 words), which was weighted at $20 \%$ of the course grade. I provided a handout outlining how to write a research proposal. The purpose of this assessment was to offer initial feedback on the question, theories, and case studies students had chosen to explore and offer direction to help them develop their essay ideas. ${ }^{65}$ Students were given written feedback within a week of submission in order to give them time (above five weeks) to use the feedback and write their final research essay (3000 words, weighted at $80 \%$ of the course grade). Extensive written feedback was provided on final essays to encourage further development in future modules.

\section{Evaluating emotions and critiques}

In offering feedback on the module, one student said:

The module was both engaging and interesting as each topic enabled me to explore multiple areas of law, while also relating them to our own emotions and experiences ... I found it consistently allowed me to think about law in a way that other modules don't encourage.

The student evaluations of the module were encouraging and positive in relation to the passion underscoring the teaching. ${ }^{66}$ However, I identified a number of key issues that need to be addressed in future classes. In order to develop discussion-based "deep learning" in future seminars, I need to develop some new learning activities. For example, I could get a student (or two of them in case one is away) to be "on call" to ensure all students participate. This student could deliver a short summary of the reading or be asked to share some media (article, tweet, YouTube clip, etc.) with the class where a particular emotion (the topic of the week's seminar) is relevant. In addition to their independent research, they could also use Pinterest to create boards of articles, clips, songs, memes, and other content related to the specific topic and bring them to class for discussion. This would give students greater control of the content used to trigger reflection on the topic, relevant to their own cultural and social background. This sharing could also be used to cultivate a collegial intimacy between students and this

\footnotetext{
${ }^{65}$ Alex Deagon, "Collaborating with Students to Create Law Assessment: A Case Study" (2017) 29(2) Bond Law Review, Article no 2, 26.

${ }^{66}$ See Sally Bradley, Emma Kirby and Manuel Madriaga, "What Students Value as Inspirational and Transformative Teaching" (2015) 52 Innovations in Education and Teaching International 231.
} 
comfort could facilitate greater conversation among their peers in the class on the topic (by using a variety of texts or stimuli to anchor the initial class conversations).

The module feedback also indicated to me that I should provide some greater direction and feedback, so students feel comfortable when discussing a topic. ${ }^{67}$ For example, this could include initially providing some broad questions as a starting point for students when they are asked to prepare a short summary of the reading or tips for selecting a media extract. In a module that demands critical reflection on law and emotion, rather than rehearsing the arguments made in the readings, I could also offer alternative methods of presenting content (such as online discussion forums, mini moots, etc.) so students do not feel confined to "traditional" formats (such as PowerPoint presentations). "On call students" should ask questions of fellow students as a way to develop intragroup feedback rather than just demonstrating class participation by responding to the questions asked by the teacher. ${ }^{68}$

Surprise is an important part of teaching and learning. ${ }^{69}$ There were several moments in teaching when I was disoriented or surprised by a particular response to a question. For example, I was stunned when a student implied homosexuality was immoral. For a gay man, such an implication became immediately emotional. It was fortunate that, in that moment, another student was willing to respectfully challenge it. Yet, moments like that remind us why, as teachers, we must account for our own emotions when responding to students. We should be careful when probing what has generated the student's response to challenge the assumptions underpinning a bigoted statement without policing anger or hostility. ${ }^{70}$ This involves emotional, as well intellectual, labour that we need to find ways to manage. ${ }^{71}$

Surprise also generates pleasure for students and teachers. The final essays, while varying in quality, demonstrated that students had genuinely engaged with a topic of interest to them and surprised themselves at what they discovered in writing about their topics. Having assessed their essays in first year, I found the depth of critical engagement was surprising. Many students, however, either struggled to develop their ideas beyond a superficial identification of emotion or lost track of emotion entirely in favour of more familiar doctrinal analysis. From the feedback and assessments, I had failed to anticipate that writing about emotion was an enormously confronting task for law students who have been trained to avoid using personal pronouns ("I") in assessment and taught to avoid using non-legal sources when writing an essay. As law teachers, we need to reflect on the pedagogical ideology that structures our teaching and find ways to anticipate (in order to address) a particular query or challenge. ${ }^{72}$

\footnotetext{
${ }^{67}$ Hess (n 49) 87.

${ }^{68}$ This is particularly relevant given COVID-19 and the need to transition to online learning (at least for lecture formats) for the foreseeable future. For an excellent discussion of ways to build inclusive online learning communities during the pandemic, see Jesse Stommel, "How to Build an Online Learning Community: 6 Theses" (Jesse Stommel, 19 May 2020) <www.jessestommel.com/how-to-build-an-online-learning-community -6-theses/> accessed 2 June 2020.

${ }^{69}$ See Eve Kosofsky Sedgwick, Touching Feeling: Affect, Pedagogy, Performativity (Duke University Press 2003$) 146$.

${ }^{70}$ Gray and Nicholas (n 53) 279-81.

${ }^{71}$ See Arlie Russell Hochschild, The Managed Heart: Commercialization of Human Feeling (University of California Press 1983).

${ }^{72}$ Brookfield (n 27) 88; Hess (n 49) 107.
} 


\section{Conclusion}

In Pedagogy of the Oppressed, Paulo Freire argues:

In problem posing education, people develop their power to perceive critically the way they exist in the world with which and in which they find themselves; they come to see the world not as a static reality, but as a reality in process, in transformation. ${ }^{73}$

Freire's work at the time spoke to the enormous challenges facing activist-teachers in Brazil who wished to engage in critical forms of pedagogy that enabled people to understand the social and economic conditions that shaped how they thought and lived. His work was animated by hopes for a future where education was pursued less as the passive "banking" of knowledge and more as a critical, collective, self-reflexive practice of freedom. ${ }^{74}$ Law and Emotion represents this hope, within the context of an undergraduate legal curriculum, by critically engaging law students in contemporary legal debates about social justice claims and creating spaces for using emotion as a lens to reimagine, discuss, and critique legal problems and pursuits. Instead of structuring the study of a legal problem or pursuit within the boundaries of a subdiscipline of law and/or national jurisdiction (which is typically the case with core LLB modules), I used emotion as a lens to highlight connections between the emotional personal experiences of students (such as sexual disgust and border fears) and the legal organisation of emotional public issues (such as the criminalisation of gay sex and restrictive refugee laws). This pedagogical approach presents an enormous disciplinary challenge, especially as both the inclusion of emotion and the pursuit of critical legal studies are still treated with hostility in law schools that privilege doctrinal forms of study and the legal profession more generally. ${ }^{75}$ But emotions saturate both law and legal classrooms. We do a disservice to our students (many of whom will go on to work within the legal system) if we fail to take seriously how emotion organises the study of law and how the practice of law is fundamentally emotional.

This paper has mapped out the design and development of such a pedagogical pursuit by showing how emotion can function as both a scholarly object of legal analysis and an academic strategy for reflective legal learning. It is clear, however, that institutional constraints limit the "queer" possibilities of teaching law and emotion. Law electives, especially those that rely on small group teaching (such as seminars of 10 students), are becoming increasingly difficult to justify as institutional demands for "cost effectiveness" increase. However, the pedagogical approaches outlined in this paper need not be confined to specially designed Law and Emotion modules. Legal curricula, especially those that seek to understand and critique the social dimensions of law, can bring emotion (in)to the classroom by simply making space to acknowledge and address how emotions have an impact on legal issues and/or how students engage with those issues. This could be done as a complement to, rather than a substitute for, conventional classrooms discussions about precedents and how to apply them to hypothetical problem scenarios. This is not about creating "safe spaces" or generating "snowflake students". Rather, it is about developing students' emotional literacy and using emotion as a resource to encourage richer intellectual debates about the theory and practice (or, as Freire would say, "praxis") of law. Taking emotion seriously in law

\footnotetext{
${ }^{73}$ Paulo Freire, Pedagogy of the Oppressed (Myra Bergman Ramos tr, Penguin 1970) 56.

${ }^{74}$ ibid 81.

${ }^{75}$ See Susan Bandes (ed), The Passions of Law (NYU Press 1999).
} 
schools is vital if students, lawyers, and scholars are to engage with pressing legal problems.

\section{Acknowledgments}

I would like to thank the anonymous reviewers and Chris Ashford for their generous comments on earlier drafts of this paper. This paper emerged from reflections I did as part of the PGCert in Learning and Teaching in Higher Education. Law and Emotion would not have been possible without colleagues and students at Keele University who contributed to the design and development of the module. I would like to thank them all for their work and support.

\section{Disclosure statement}

No potential conflict of interest was reported by the author. 